\title{
THE PRINCIPLE OF ZAKAT, INFAQ, AND SHADAQAH ACCOUNTING BASED SFAS 109
}

\author{
Anang Ariful Habib \\ Program Pascasarjana Universitas Jember \\ anang_ariful@yahoo.co.id
}

\begin{abstract}
The purpose of this research was to determine whether PSAK 109 about accounting of zakat, infaq and shadaqah that made by the government together with IAI that used as guidelines for the preparation of financial statement on the organization of zakat has been applied to the Amil Zakat, infaq and Shadaqah Agency (BAZIS). This research is the study of literature review in which the emphasis will be on the use of secondary data. Stages in this study, namely: formulating the problem, look for sources of literature that discusses the topic under study, evaluating the data, and analyze with interpret. Results from the study showed that most BAZIS in making financial report has not been guided by PSAK 109, which is still a lot of companies that use financial simple reporting with basic cash method, where in the recording of all transactions is only done when issuing and receiving cash.
\end{abstract}

Keywords: accounting of zakat, infaq and shadaqah, PSAK 109, BAZIS

Abstrak: Tujuan penelitian ini adalah untuk mengetahui apakah PSAK 109 tentang akuntansi zakat, infaq dan shadaqah yang dibuat oleh pemerintah bersama dengan IAI yang dijadikan sebagai pedoman untuk pembuatan laporan keuangan pada organisasi pengelola zakat sudah diterapkan pada Badan Amil Zakat, Infaq, dan Shadaqah (BAZIS). Penelitian ini adalah studi kepustakaan di mana penekanan dilakukan pada penggunaan data sekunder. Tahapan dalam penelitian ini, yaitu: memformulasikan permasalahan, mencari sumber literature yang membahas topik yang diteliti, mengevaluasi data, dan menganalisis serta menginterpretasikannya. Hasil dari penelitian menunjukkan bahwa sebagian besar BAZIS dalam pembuatan laporan keuangan belum berpedoman pada PSAK 109, yaitu masih banyak yang menggunakan pelaporan keuangan secara sederhana dengan metode cash basic, dimana pencatatan dari seluruh transaksi hanya dilakukan pada saat mengeluarkan dan menerima kas.

Kata Kunci: akuntansi zakat, infaq dan shadaqah, PSAK 109, BAZIS.

Islam adalah ajaran rahmatan lill alamin, yang tujuan utamanya sebagai pembawa kesejahteraan, keberkahan, kedamaian dan keamanan bagi seluruh umat manusia di dunia. Selain itu, islam mengajarkan untuk saling tolong menolong antar sesama umat manusia. Terlebih lagi, Allah Swt telah memberikan sumber daya alam, dan yang lainnya dalam jumlah yang begitu melimpah untuk digunakan manusia sebagai khalifah di muka bumi. Indonesia mayoritas pendudukannya beragama islam, sehingga memiliki potensi yang dapat dikembangkan menjadi salah satu instrument pemerataan pendapatan, khususnya yang masyarakat muslim. Konsep tolong menolong dalam islam tercermin dalam kewajiban manusia mengeluarkan zakat. 
Zakat adalah salah satu dari lima rukun islam yang wajib dilaksanakan. Dalam al Qur'an, tidak kurang dari 28 ayat Allah Swt, menyebutkan perintah zakat, diantaranya adalah surat Al Baqoroh ayat 43, yang artinya "Dirikanlah shalat, tunaikanlah zakat, serta ruku'lah bersama orang-orang yang ruku” (Departemen Agama. 1989: 43). Zakat bermanfaat bagi masyarakat untuk mensucikan harta yang diperolehnya. Zakat juga bisa dikatakan sebagai pajak yang berkonotasi spiritual (Gambling and Karim, 1986). Pada konteks ekonomi dan sosial, zakat dimaksudkan untuk mencapai keadilan sosial. Zakat, infaq, dan shodaqoh (ZIS) merupakan bagian dari kedermawanan (filantropi) dalam konteks masyarakat muslim. Dalam menghimpun dana zakat, infaq dan shadaqah, telah menjamur badan amil zakat yang bertujuan untuk mempermudah masyarakat dalam menyalurkan dana zakat, infaq dan shadaqah (Sarif and Kamri, 2009).

Badan Amil Zakat, Infaq, dan Shadaqah (BAZIS) adalah lembaga yang melayani kepentingan publik dalam menghimpun dan menyalurkan dana zakat, infaq dan shadaqah pada masyarakat. Sebagai suatu organisasi terbuka, BAZIS memiliki kepentingan baik sacara internal maupun eksternal. Hal ini memberikan tanggung jawab kepada BAZIS untuk akuntabilitas dan transparansi pengelolaan dana kepada semua pihak yang memiliki kepentingan. Dengan adanya laporan keuangan yang tersusun secara rapi dan terstruktur, maka dapat meningkatkan kepercayaan dan menjaga amanah masyarakat terhadap BAZIS sebagai lembaga "philanthropy” yang akuntabel.

Pengelolaan dana zakat secara profesional dibutuhkan suatu badan khusus yang bertugas sesuai dengan ketentuan syariah islam mulai dari perhitungan, pengumpulan, dan pengelolaan zakat hingga pentasyarufannya. Ketentuan zakat yang diatur dalam islam menuntut pengelolaan zakat (Amil) harus akuntabel dan transparan. Semua pihak dapat mengawasi dan mengkontrol secara langsung. Ketidakpercayaan donatur (muzaki dan munfiq) disebabkan belum transparansinya laporan penggunaan dana ZIS yang dikelola amil zakat kepada masyarakat. Oleh karena itu, aturan pelaporan penggunaan dana zakat diperlakukan pada semua Amil di Indonesia. Menurut Istutik (2013) bahwa laporan keuangan menjadi salah satu media untuk pertanggungjawaban operasional BAZIS, yaitu dalam menghimpun dan menyalurkan dana zakat, infaq, dan shadakah (ZIS).

Laporan keuangan dapat dinyatakan akuntabel dan transparan, maka dibutuhkan standar akuntansi yang mengaturnya. Hal ini berbeda dengan entitas syariah, aktivitas pengumpulan dan penyaluran dana ZIS juga dilakukan dalam rangka melaksanakan fungsi sosial selain fungsi komersial, sehingga komponen laporan keuangan yang dimuat dalam PSAK 101 juga memiliki laporan sumber dan penggunaan dana ZIS. BAZIS yang didirikan 
khusus hanya untuk mengelola dana ZIS, maka penyusunan laporan keuangannya tidak menganut PSAK 101 akan tetapi menggunakan pedoman PSAK 109, standar akuntansi yang mengatur tentang zakat, infaq dan shadaqah. Tentu hal-hal yang tidak diatur dalam PSAK 109 dapat menggunakan PSAK yang terkait sepanjang tidak bertentangan dengan syariah islam.

Menurut Wibisono yang dikutip oleh Istutik, laporan keuangan BAZIS dalam prakteknya tidak seragam karena tidak adanya standar sehingga jika lembaga zakat sama melaporkan penyaluran zakat, belum tentu telah mentasyarufkan. Ada kemungkinan BAZIS dianggap belum menyalurkan karena dipergunakan untuk kepentingan publik. Amil sebagai sebuah entitas harus bertanggung jawab kepada masyarakat dan harus lebih accountable, transparan dan profesional di mata publik. (Istutik, 2013)

Terkait dari uraian di atas, penulis tertarik untuk memahami dan mengkaji mengenai perlakuan yang akuntansi zakat, infaq, dan shadaqah yang dilakukan BAZIS. Untuk itu penulis mengambil tema "Kaidah perlakuan akuntansi zakat, infaq, dan shadaqah berbasis PSAK 109”. Apakah dalam hal ini pihak BAZIS telah menerapkan PSAK 109 dalam penyajian laporan keuangannya.

\section{KAJIAN PUSTAKA}

\section{Pengertian Zakat, Infaq, dan Shadaqah}

Zakat, infaq, dan shadaqah (ZIS) diyakini merupakan ibadah yang berperanstrategis dalam mendorong pemerataan kemakmuran masyarakat suatu negara. Zakat, infaq dan shadaqah dapat memberikan jaminan sosial bagi masyarakat yang membutuhkan kedermawanan secara finansial. Dalam hal ini masyarakat yang dimaksud adalah yang memenuhi kriteria sebagai penerima (mustahiq). Zakat, infaq, dan shadaqah merupakan bagian dari kedermawanan (filantropi) dalam konteks masyarakat muslim.

Zakat merupakan kewajibanbagian dari setiap muslim yang mampu serta menjadi unsur dari rukun islam, sedangkan infaq dan shadaqah merupakan wujud kecintaan hamba terhadap nikmat dari Allah Swt yang telah diberikan kepadanya sehingga seorang hamba rela menyisihkan sebagian hartanya untuk kepentingan agama baik dalam rangka membantu sesama maupun perjuangan dakwah islamiyah.

Makna zakat menurut bahasa adalah tumbuh dan berkembang, bisa juga bermakna menyucikan karena zakat akan mengembangkan pahala pelakunya dan membersihkan dari dosa. Menurut syariat, zakat ialah hak wajib dari harta tertentu pada waktu tertentu. 
Sedangkan makna zakat menurut istilah adalah sejumlah harta yang khusus, dan dibagikan dengan syarat-syarat tertentu (Mu'is, 2011: 22).

Menurut PSAK NO. 109, pengertian zakat adalah harta yang wajib dikeluarkan olehmuzzaki sesuai dengan ketentuan syariah untuk diberikan kepada yang berhakmenerimanya (mustahiq). Infaq adalah mengeluarkan harta yang mencangkup zakat dan non zakat. Infaq ada yang wajib dan ada yang sunnah. Infaq yang wajib diantaranya adalah zakat, kafarat, dan nadzari. Sedangkan infaq yang sunnah diantaranya adalah infaq kepada fakir miskin sesama muslim, infaq bencana alam, dan infaq kemanusiaan.

Menurut PSAK 109 shadaqah adalah harta yang diberikan secara sukarela oleh pemiliknya baik peruntukannya dibatasi (ditentukan) maupun tidak dibatasi. Sedekah adalah pemberian harta pada orang-orang fakir miskin, orang yang membutuhkan, atau pihak-pihak lain yang berhak untuk menerima shadaqah tanpa disertai imbalan, tanpa paksaan, tanpa batasan jumlah, kapan saja dan berapapun jumlahnya (Mu'is, 2011: 23).

Definisi dari ketiga istilah diatas dapat disimpulkan bahwa perbedaan antara zakat, infaq dan shadaqah adalah: bahwa zakat berati kewajiban atas harta tertentu untuk kelompok tertentu dan pengeluaran pada waktu tertentu juga, sedangkan infaq adalah mengeluarkan harta yang mencakup zakat dan non zakat, ada yang wajib dan yang sunnah, kemudian kalau shadaqah dapat bermakna infaq, zakat, dan kebaikan materi maupun non materi.

\section{Sasaran (Masharif), Hikmah, dan Tujuan Zakat}

Masharifuz zakat (orang yang berhak menerima zakat) adalah orangorangyang berhak menerima harta zakat dan terbagi atas delapan golongan, yaitu fakir, miskin, amil zakat, golongan muallaf, dana untuk memerdekakan budak, orang yang berhutang (gharimin), dijalan Allah Swt (fi sabilillah), dan ibnusabil. Sesuai dengan firman Allah dalam QS. At Taubah: 60, "sesungguhnya zakat itu hanyalah untuk orang-orang fakir, orang-orang miskin, pengurus pengurus zakat, para muallaf yang dibujuk hatinya, untuk memerdekakan budak, orang-orang berhutang, untuk jalan Allah, dan orang-orang yang sedang dalam perjalanan, sebagai suatu ketetapan yang diwajibkan Allah dan Allah Maha Mengetahui lagi Maha Bijaksana”.

Penjelasan mengenai apa yang dimaksud masharifuz zakat (pihak yang berhak menerima zakat) adalah sebagai berikut:

1. Fakir, adalah kelompok orang yang tidak memiliki pekerjaan dan penghasilanuntuk memenuhi kebutuhan pokok dirinya sendiri dan juga keluarganya. 
2. Miskin, merupakan kelompok orang yang berbeda dengan fakir, merekamemiliki penghasilan akan tetapi tidak mencukupi kebutuhan pokok hidupnya dan keluarganya. Penyaluran untuk fakir dan miskin melalui pemenuhankebutuhan primer yang bersifat konsumtif atau produktif melalui program pemberdayaan untuk meningkatkan kesejahteraan hidup.

3. Amil adalah kelompok pengelola dan petugas zakat yang mendapat bagian dari zakat sebesar $12,5 \%$ untuk melaukan tugas-tugasnya dan sebagai biaya administrasi yang harus dikeluarkan dalam pengelolaan dan pendistribusian dana zakat.

4. Muallaf, kelompok orang yang baru masuk islam, dan dianggap masih lemah imannya sehingga harus diperkuat. Saat ini penditribusian untuk muallaf dapat diberikan pada lembaga-lembaga dakwah yang bergerak dalam syiar islam.

5. Memerdekakan budak, artinya bagian zakat yang diguanakn untuk membebaskan budak belian dan menghilangkan semua bentuk sistem perbudakan.

6. Gharimin, yaitu kelompok orang yang berutang yang tidak mampu untukmelunasinya, kriterianya adalah orang yang berhutang untuk memenuhi nafkah keluarganya atau berhutang karena kehilangan hartanya disebabkan suatu bencana.

7. Fisabilillah, yaitu orang yang dalam jalan Allah Swt, untuk saat ini pendistribusiannya pada lembaga pendidikan islam, pembagunan masjid dan syiar da'i.

8. Ibnu sabil yaitu orang yang kehabisan bekal dalam perjalanan, untuk saat inidapat diaplikasikan pada pemberian beasiswa pendidikan karena ketiadaandana atau untuk membina dan membiayai anak terlantar dan sebagainya. Zakat merupaka ibadah yang memiliki banyak arti dalam kehidupan umat manusia terutama ummat islam.

Zakat memiliki banyak hikmah, baik yang berkaitan dengan hubungan manusia dengan sang pencipta, maupun hubungansosial kemasyarakatan di antara manusia adalah:

1. Menyucikan diri dari kotoran dosa, memurnikan jiwa, menumbuhkan akhlak mulia menjadi murah hati, memiliki rasa kemanusiaan, dan mengikis sifat bakhil (kikir), serta serakah sehingga dapat merasakan ketenangan batin, karena terbebas dari tuntutan Allah Swt dan tuntutan kewajiban masyarakat.

2. Memberantas penyakit iri hati, rasa benci, dan dengki dari diri manusia yang biasa timbul ketika melihat kecukupan atau kelebihan orang disekitarnyadengan kemewahan, sedangkan ia sendiri tak punya apa-apa dan tidak adauluran tangan dari mereka (orang kaya) kepadanya. 
3. Dapat menolong membina, dan membangun kaum yang lemah untuk memenuhi kebutuhan pokok hidupnya, sehingga mereka dapat melaksanakan kewajiban- kewajibannya terhadap Allah Swt.

4. Dapat menunjang terwujudnya sistem kemsyarakatan islam yang berdiri diatas prinsipprinsip ummatan wahidan, musawah (persamaan derajat, hak dan kewajiban), ukhuwah islamiyah, dan takafulijtima'i (tanggung jawab sosial bersama).

5. Menjadi unsur penting dalam keseimbangan dalam distribusi harta sosial (social distruction) keseimbangan dalam kepemilikan harta (social ownership), dan keseimbangan tanggung jawab individu dalam masyarakat.

6. Zakat adalah ibadah maliyyah yang mempunyai dimensi dan fungsi ekonomi atau pemerataan karunia Allah Swt dan merupakan perwujudan solidaritas sosial, pembuktian persaudaraan islam, pengikat persaudaraan umat dan bangsa sebagai penghubung antara golongan kuat dan lemah

7. Dapat mewujudkan tatanan masyarakat yang sejahtera, dimana hubungan seseorang dengan yang lainnya rukun, damia, dan harmonis yang dapat menciptakan situasi yang tentram dan aman lahir dan batin (Elsi Kartika sari, 2007: 13).

Menurut Fahrur Mu'is (2011:32), tujuan disyariatkannya zakat adalah sebagi berikut:

(1) Mengangkat derajat fakir miskin; (2) Membantu memecahkan masalah para gharimin, ibnu sabil; (3) Membina tali persaudaraan sesama ummat islam; (4) Menghilangkan sifat kikir dari pemilik harta; (5) Membersihkan sifat dengki dan iri hati dari orang-orang miskin.

\section{Dasar kewajiban membayar zakat}

Adapun dalil yang menjadi dasar kewajiban membayar zakat, antara lain:

1. Al Qur'an

(a) Surat At-Taubah ayat 103:

"ambillah zakat dari sebagian harta mereka, dengan zakat itu kamu membersihkan dan mensucikan mereka dan berdoalah untuk mereka. Sesungguhnya doa itu (menjadi) ketentraman jiwa bagimereka, dan Allah Maha mendengar lagi Maha Mengetahui.”

(b) Surat Al-Baqarah ayat 43:

"Dan dirikanlah sholat, tunaikanlah zakat dan ruku'lah beseta orangorangyang ruku."

(c) Surat Al-Hadid ayat 7:

"Berimanlah kamu kepada Allah dan Rasul-nya dan nafkahkanlah sebagian dari hartamu yang Allah telah menjadikan kamumenguasainnya. Maka orang-orang yang beriman diantara kamu dan menafkahkan (sebagian) hartanya memperoleh pahala yang besar." 
(d) Surat Adz-Dzaariyat ayat 19:

"Dan pada harta-harta mereka ada hak untuk orang miskin yangmeminta dan orang miskin yang tidak mendapat bagian."

(e) Surat An-Nisa ayat 77:

"Dirikanlah sholat dan bayarlah zakat hartamu."

2. As Sunnah (Hadist)

(a) Nabi Muhammad SAW bersabda:

"Islam dibangun diatas lima rukun; syahadat tiada tuhan selain Allah dan Muhammad adalah utusan-Nya, menegakkansholat, membayar zakat, berpuasa ramadhan, dan menunaikan haji bagi yang mampu" (HR Bukhari dan Muslim).

(b) Dari Ali RA.:

"Sesungguhnya Allah mewajibkan zakat atas orangorangkaya dari umat Islam pada harta mereka dengan batas sesuai kecukupan fuqara diantara mereka. Orang-orang fakir tidak akankekurangan pada saat mereka lapar atau tidak berbaju kecuali karena ulah-ulah orang kaya diantara mereka. Ingatlah bahwa Allah akan menghisab mereka dengan keras dan menghisab mereka dengan pedih" (HR Thabrani).

Muhammad (2005:159) menguraikan bahwa pengertian yang dapatdipetik dari firman Allah Swt diatas adalah bahwa zakat merupakan kewajiban dari setiap muslim yang memenuhi nisab (batas minimal hara yang harusdikeluarkan zakatnya), agar dapat mensucikan jiwa, individu maupun masyarakat. Zakat merupakan rukun Islam yang paling tampak sisi sosialnya dibanding rukun lainnya. Zakat adalah hak orang lain yang melekat pada suatu individu.

\section{Harta yang wajib dikeluarkan zakatnya}

Dalam Undang-Undang Nomor 38 Tahun 1999 tentang pengelolaan zakat Bab IV Pasal 11, zakat terdiri atas: Zakat mal yang berkaitan dengan harta dan zakat fitrah yang berkaitandengan jiwa. Kemudian Harta yang dikenai zakat adalah:

a. Emas, perak, dan uang

Emas dan perak yang disimpan (dimiliki) bila sampai nishab, wajib dikeluarkan zakatnya setiap tahun, sebagaimana firman Allah Swt dalam surat At-Taubah ayat 34-35:

"Hai orang-orang yang beriman, sesungguhnya sebagian besar dariorang-orang alim Yahudi dan rahib-rahib Nasrani benar-benar memakan harta orang dengan jalan batil dan mereka menghalang-halangi(manusia) dari jalan Allah. Dan orangorang yang menyimpan emas danperak dan tidak menafkahkannya pada jalan Allah, 
maka beritahukanlah kepada mereka, (bahwa mereka akan mendapat) siksa yang pedih, pada hari dipanaskan emas perak itu dalam neraka jahanam, lalu dibakardengannya dahi mereka, lambung dan punggung mereka (lalu dikatakan kepada mereka: "inilah harta bendamu yang kamu simpan untuk dirimu sendiri, maka rasakanlah sekarang (akibat dari) apa yang kamu simpan itu”.

Besarnya nisab untuk emas jika telah mencapai 85 gram dan perak 595 gram jika telah berlalu setahun maka wajib dikeluarkan zakatnya sebesar 2,5\%. Sebagian besar ulama memandang bahwa zakat uang itu, wajib, karena uang atau uang kertas (banknote) kedudukannya sama dengan emas dan perak dalam penggunaannya, dan ia dapat dipertukarkan dengan perak tanpa ada kesulitan.

b. Perdagangan dan perusahaan.

Zakat perdagangan atau barang dagangan adalah zakat yang dikenakan kepada barangbarang dagangan yang bukan emas dan perak, baik yang dicetak, seperti pound dan riyal, maupun yang tidak dicetak, seperti perhiasan wanita (Arifin, 2011:93). Hal tersebut sesuaidengan firman Allah SWT dalam surat Al-Baqarah ayat 2 :"Hai orang-orang beriman nafkahkanlah (di jalan Allah) sebagian dari hasil usahamu yang baik-baik dan sebagian dari apa yang kami keluarkan dari bumi untuk kamu".

Pada umumnya zakat perusahaan, oleh para ulama masakini disamakan dengan zakat perdagangan. Hal tersebut karena ada kemiripan dalam hal menjual/memperdagangkan hasil produksi suatu perusahaan atau usaha untuk mencari keuntungan dari hasil jual-beli barang atau jasa. Besarnya nisab untuk zakat perdagangan setara dengan emas 85 gram setelah berlalu satu tahun wajib dikeluarkan zakatnya sebesar 2,5\%. Cara perhitungannya yaitu, pada awal tahun dihitung nilai barang dagangannya, jika sudah mencapai nishab, pada akhir tahun dihitung kembali apakah telah mencapai nisab atau belum. Jika telah mencapai nisab, harus dikeluarkan zakatnya sebesar 2,5\%.

c. Hasil pertanian, hasil perkebunan, dan hasil perikanan.

Zakat pertanian adalah zakat yang dikenakan pada produk pertanian, setiap panen mencapai nishab. Sebagaimana disebutkandalam Al-Qur'an (Al-An'am 6:141): “Makanlah dari buahnya (yang bermacam-macam itu) bila dia berbuah, dan tunaikanlah haknya di hari memetik hasilnya (dengan disedekahkan kepada fakir miskin), dan janganlah kamu berlebihlebihan. Sesungguhnya Allah tidak menyukai oran-orang yang berlebihan”.

d. Hasil pertambangan.

Barang tambang adalah benda-benda yang ada di dalam bumi yangmempunyai nilai ekonomis, baik berbentuk padat (emas, perak dan lain-lain), cair (minyak), dan gas. Dan juga 
yang didapatkan dari laut, seperti mutiara dan lain-lain. Besarnnya nishab untuk hasil pertambangan senilai 85 garam emas maka wajib dikeluarkan zakatnnya sebesar 2,5\%, dengan cara menghitung nilai barang tambang, jika mencapai nisab, langsung dikeluarkan zakatnya tanpa menunggu berlalu satu tahun.

e. Hasil peternakan

Zakat peternakan merupakan kekayaan yang berupa hewan ternakyaitu kambing/domba, unta, dan sapi/kerbau. Selain hewan tersebut, dimasukkan kelomok barang dagangan (Arifin, 2011:63). Besarnya nisab untuk peternakan/hewan ternak adalah minimal berjumlah 5 ekor kambing dan unta baik jantan maupun betina, untuk sapi atau kerbau minimal berjumlah 30 ekor baik jantan maupun betina, dan untuk kambing minimal berjumlah 40 ekor setelah berlalu satu tahun.

f. Hasil pendapatan dan jasa

Zakat profesi: hasil pendapatan dan jasa dalam Al-Quran Surat Al-Baqarah diterangkan bahwa orang-orang yang beriman dianjurkan untuk menafkahkan sebagian dari hasil usaha yang baik-baik dan sebagian harta yang dikeluarkan dari perut bumi. Pendapatan dan jasa profesi termasuk dari hasil usaha yang meliputi berbagai macam profesi. Penghasilan profesi dari segi wujudnya yaitu berupa uang. Dalam hal ini berbeda dengan tanaman, dan lebih dekat dengan emas dan perak. Oleh karena itu kadar zakat profesi yang diqiyaskan dengan zakat emas dan perak, yaitu 2,5\% dari seluruh penghasilan kotor yang diperolehnya. g. Rikaz

Rikaz adalah harta temuan/karun yang terdapat di dalam perut bumi.Besaran nishab untuk rikaz senilai dengan 85 gram emas dan langsungdikeluarkan zakatnya sebesar 20\% setalah mendapatkannya tanpamenunggu berlalalu satu tahun.

\section{Pengertian Organisasi Pengelola Zakat (OPZ)}

Organisasi pengelola zakat menurut Hertanto Widodo dan Teten Kustiawan (2001: 6) adalah institusi yang bergerak di bidang pengelola zakat, infaq, dan shadaqah. Sedangkan definisi pengelola zakat menurut Undang undang nomor 38 tahun 1999 tentang Pengelolaan zakat adalah kegiatan perencanaan, pengorganisasian, pelaksanaan, dan pengawasan terhadap pengumpulan, pendistribusian dan pendayagunaan zakat. Dalam peraturan perundangundangan diakui adanya dua jenis organisasi pengelola zakat di indonesia, yaitu Badan Amil Zakat (BAZ) dan Lembaga Amil Zakat (LAZ).

Ada bebeapa karakteristik khusus yang membedakan Organisasi Pengelola Zakat (OPZ) dengn organisasi nirlaba lainnya. Menurut Hertanto Widodo dan Teten Kustiawan 
(2001: 11) ada tiga Karakteristik khusus yang membedakan Organisasi Pengelola Zakat (OPZ) dengan organisasi nirlaba lainnya, yaitu:

1. Terikat dengan aturan dan prinsip-prinsip syari'ah islam. Hal ini tidak terlepas dari keberadaan dana-dana yang menjadi sumber utama Organisasi Pengelola Zakat (OPZ) telah diatur dalam Al-Qur'an danhadist.

2. Sumber dana utama adalah dana zakat, infaq, shadaqah dan wakaq.

3. Biasanya memiliki dewan syari'ah dalam struktur organisasinya.

\section{Konsep Akuntansi Zakat, Infaq dan Shadaqah Pengertian Akuntansi Zakat}

Akuntansi syariah dapat dijelaskan melalui akar kata yang dimilikinya yakni akuntansi dan syariah. Pengertian akuntansi secara umum menurut American Accounting Association adalah suatu proses pencatatan, pengklasifikasian, pemrosesan, peringkasan, penganalisaan, dan pelaporan kejadian atau transaksi yang bersifat keuangan.

Dalam pengertian lain, akuntansi didefinisikan sebagai suatu aktivitas jasa untuk memberikan informasi kuantitatif terutama yang bersifat finansial kepada pihak-pihak yang membutuhkan informasi tersebut untuk pembuatan keputusan (Soemarso, 2002: 3). Adapun kosa kata syariah dalam bahasa arab memiliki arti jalan yang ditempuh atau garis yang seharusnya dilalui. Dari sisi terminologi bermakna pokok-pokok atauran hukum yang digariskan oleh Allah Swt untuk dipatuhi dan dilalui oleh seorang muslim dalam menjalani segala aktivitas hidupnya yaitu ibadah didunia (Nurhayati, 2009: 14).

\section{Tujuan akuntansi zakat}

Tujuan akuntansi zakat menurut Mahmudi (2008) adalah untuk: pertama memberikan informasi yang diperlukan untuk mengelola secara tepat, efisien, dan efektif atas zakat, infaq, shadaqah, hibah, dan wakaf yang dipercayakan kepada organisasi atau lembaga pengelola zakat. Tujuan ini terkait dengan pengendalian manajemen (management control) untuk kepentingan internal organisasi. Kedua memberikan informasi yang memungkinkan bagi lembaga pengelola zakat (manajemen) untuk melaporkan pelaksanaan tanggung jawab dalam mengelola secara tepat dan efektif program dan penggunaan zakat, infaq, dan shadaqah yang menjadi wewenangnya; dan memungkinkan bagi lembaga pengelola zakat untuk melaporkan kepada publik (masyarakat) atas hasil operasi dan penggunaan dana publik (dana ummat). Tujuan ini terkait dengan akuntabilitas (accountability).

\section{Perlakuan Akuntansi Zakat Menurut PSAK 109}




\section{Pengakuan dan Pengukuran Zakat, Infaq, dan Shadaqah}

1. Pengakuan awal zakat

Jika dalam bentuk kas maka sebesar jumlah yang diterima; Jika dalam bentuk nonkas maka sebesar nilai wajar aset nonkas tersebut. Penentuan nilai wajar aset nonkas yang diterima menggunakan harga pasar. Jika harga pasar tidak tersedia, maka dapat menggunakan metode penentuan nilai wajar lainnya sesuai yang diatur dalam PSAK yang relevan. Zakat yang diterima diakui sebagai dana amil untuk bagian amil dan dana zakat untuk bagian nonamil.

Penentuan jumlah atau persentase bagian untuk masing-masing mustahiq ditentukan oleh amil sesuai dengan prinsip syariah dan kebijakan amil. Jika muzakki menentukan mustahiq yang harus menerima penyaluran zakat melalui amil maka aset zakat yang diterima seluruhnya diakui sebagai dana zakat. Jika atas jasa tersebut amil mendapatkan ujrah/fee maka diakui sebagai penambah dana amil.

2. Pengukuran setelah pengakuan awal zakat

Jika terjadi penurunan nilai aset zakat nonkas, jumlah kerugian yang ditanggung harus diperlakukan sebagai pengurang dana zakat atau pengurang dana amil tergantung dari sebab terjadinya kerugian tersebut. Penurunan nilai aset zakat diakui sebagai: (a) Pengurang dana zakat, jika terjadi tidak disebabkan oleh kelalaian amil; (b) Kerugian dan pengurang dana amil, jika disebabkan oleh kelalaian amil.

3. Penyaluran zakat

Zakat yang disalurkan kepada mustahiq diakui sebagai pengurang dana zakat sebesar: a) Jumlah yang diserahkan, jika dalam bentuk kas; b) Jumlah tercatat, jika dalam bentuk aset nonkas.

4. Pengakuan awal infaq/shadaqah

Infaq/shadaqah yang diterima diakui sebagai dana infaq/shadaqah terikat atautidak terikat sesuai dengan tujuan pemberi infaq/shadaqah sebesar:

a) Jumlah yang diterima, jika dalam bentuk kas;

b) Nilai wajar, jika dalam bentuk nonkas. Penentuan nilai wajar aset nonkas yang diterima menggunakan hargapasar untuk aset nonkas tersebut. Jika harga pasar tidak tersedia, maka dapat menggunakan metode penentuan nilai wajar lainnya sesuai yang diatur dalam PSAK yang relevan. Infaq/shadaqah yang diterima diakui sebagai dana amil untuk bagian amil dan dana infaq/shadaqah untuk bagian penerima infaq/shadaqah. Penentuan jumlah atau persentase bagian untuk para penerima infaq/shadaqah ditentukan oleh amil sesuai dengan prinsip syariah dan kebijakan amil. 
5. Pengukuran setelah pengakuan awal infaq/shadaqah

Infaq/shadaqah yang diterima dapat berupa kas atau aset nonkas. Aset nonkas dapat berupa aset lancar atau tidak lancar. Aset tidak lancar yang diterima oleh amil dan diamanahkan untuk dikelola dinilai sebesar nilai wajar saat penerimaannya dan diakui sebagai aset tidak lancar infaq/shadaqah. Penyusutan dari aset tersebut diperlakukan sebagai pengurang dana infaq/shadaqah terikat apabila penggunaan atau pengelolaanaset tersebut sudah ditentukan oleh pemberi.

Amil dapat pula menerima aset nonkas yang dimaksudkan oleh pemberi untuk segera disalurkan. Aset seperti ini diakui sebagai aset lancar. Aset inidapat berupa bahan habis pakai, seperti bahan makanan; atau aset yangmemiliki umur ekonomi panjang, seperti mobil ambulance. Aset nonkas lancar dinilai sebesar nilai perolehan sedangkan aset nonkas tidak lancar dinilai sebesar nilai wajar sesuai dengan PSAK yang relevan. Penurunan nilai aset infaq/shadaqah tidak lancar diakui sebagai: (a) pengurang dana infaq/shadaqah, jika terjadi bukan disebabkan oleh kelalaianamil; (b) kerugian dan pengurang dana amil, jika disebabkan oleh kelalaian amil. Dalam hal amil menerima infaq/shadaqah dalam bentuk aset (nonkas) tidak lancar yang dikelola oleh amil, maka aset tersebut harus dinilai sesuai dengan PSAK yang relevan. Dana infaq/shadaqah sebelum disalurkan dapat dikelola dalam jangka waktu sementara untuk mendapatkan hasil yang optimal. Hasil dana pengelolaan diakui sebagai penambah dana infaq/shadaqah.

\section{Penyaluran infaq/shadaqah}

Penyaluran dana infaq/shadaqah diakui sebagai pengurang danainfaq/shadaqah sebesar jumlah yang diserahkan jika dalam bentuk kas dan nilai tercatat aset yang diserahkan jika dalam bentuk aset nonkas.

Penyaluran infaq/shadaqah kepada amil lain merupakan penyaluran yangmengurangi dana infaq/shadaqah sepanjang amil tidak akan menerima kembali aset infaq/shadaqah yang disalurkan tersebut. Penyaluran infaq/shadaqah kepada penerima akhir dalam skema dana bergulir dicatat sebagai piutang infaq/shadaqah bergulir dan tidak mengurangi dana infaq/shadaqah.

\section{Dana nonhalal}

Penerimaan nonhalal adalah semua penerimaan dari kegiatan yang tidaksesuai dengan prinsip syariah, antara lain penerimaan jasa giro atau bunga yangberasal dari bank konvensional. Penerimaan nonhalal pada umumnya terjadi dalam kondisi darurat atau kondisi yang tidak diinginkan oleh entitas syariah karena secara prinsip dilarang. Penerimaan non- 
halal diakui sebagai dana nonhalal, yang terpisah dari dana zakat, dana infaq/sedekah dan dana amil. Aset nonhalal disalurkan sesuaidengan syariah.

\section{Komponen Laporan Keuangan PSAK: 109}

Komponen laporan keuangan yang lengkap yang sesuai dengan pedoman PSAK 109 terdiri dari:

1) Neraca (laporan posisi keuangan)

2) Laporan perubahan dana

3) Laporan perubahan aset kelolaan

4) Laporan arus kas

5) Catatan atas laporan keuangan

Gambar 2.1

Contoh Neraca

Noraca ( Laporan PoslsI Kouangan)

$B A Z$ "XXX"

Per 31 Desember $2 \times X 2$

\begin{tabular}{|c|c|c|c|}
\hline Keterangan & $R p$ & Keterangan & Rp \\
\hline $\begin{array}{l}\text { Aset } \\
\text { Asst I ancar } \\
\text { Kas dan satara kas } \\
\text { instruman kallangan } \\
\text { Piltang } \\
\text { Asct tidak foncor } \\
\text { Aset tetap } \\
\text { Akumulaci penyusutan }\end{array}$ & $\begin{array}{l}x \times x \\
x x x \\
x x x\end{array}$ & 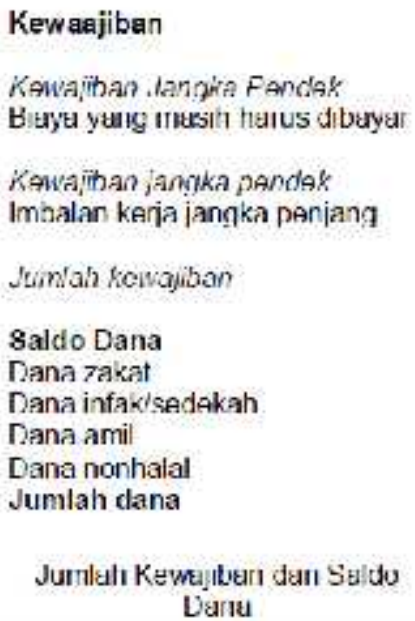 & $\begin{array}{l}\mathrm{xxx} \\
\mathrm{xxx} \\
\mathrm{xxx} \\
\mathrm{xxx} \\
\mathrm{xxx} \\
\mathrm{xwx} \\
\mathrm{x} \mathrm{xx}\end{array}$ \\
\hline
\end{tabular}

(Sumber. Dadaptas! darl CO PSAK 108 Tentang AKunansi Zakat, dan Maki Sedekan) 
Gambar 2.2

Contoh Laporan Perubahan Dana

Lapuran Perubalran Darea

$B A Z$ " $X X X "$

Untuk periode yang berakhir 31 Desember $2 \times \times 2$

\begin{tabular}{|c|c|}
\hline Keterangan & $R p$ \\
\hline $\begin{array}{l}\text { DANA ZAKAT } \\
\text { Penerimaan } \\
\text { Penerimaan dani muzakki } \\
\text { muzakki entitas } \\
\text { muzakki individual } \\
\text { Hasil penempatan } \\
\text { Jumlah penerimaan dana zakat } \\
\text { Bagian amil atas penerimaan dana zakat } \\
\text { Jumlah penerimaan dana zakat setelah bagian amil }\end{array}$ & $\begin{array}{l}(x x 0) \\
(x x x) \\
(x x x) \\
(x x x) \\
(x x x) \\
\frac{(x x x)}{(x x x)} \\
x x x \\
\frac{x x x}{x x x}\end{array}$ \\
\hline $\begin{array}{l}\text { UANA inI AK/ StUEKAH } \\
\text { Penerimaan } \\
\text { Infak/sedekah terikat atau muqayyadah } \\
\text { Infak/sedekah tidak terikat atau mutlaqah } \\
\text { Bagian amil atas penerimaan dana infak/sedekah } \\
\text { Hasil pengelolaan } \\
\text { Jum/ah penerimaan dana infag/sedekah } \\
\text { Penyaluran } \\
\text { Infak/sedekah terikat atau muqayyadah }\end{array}$ & $\begin{array}{l}x 00 \\
x 0 x \\
(x 0 x) \\
\frac{x 0 x}{x x o x} \\
(x x x) \\
(x x x) \\
\end{array}$ \\
\hline
\end{tabular}




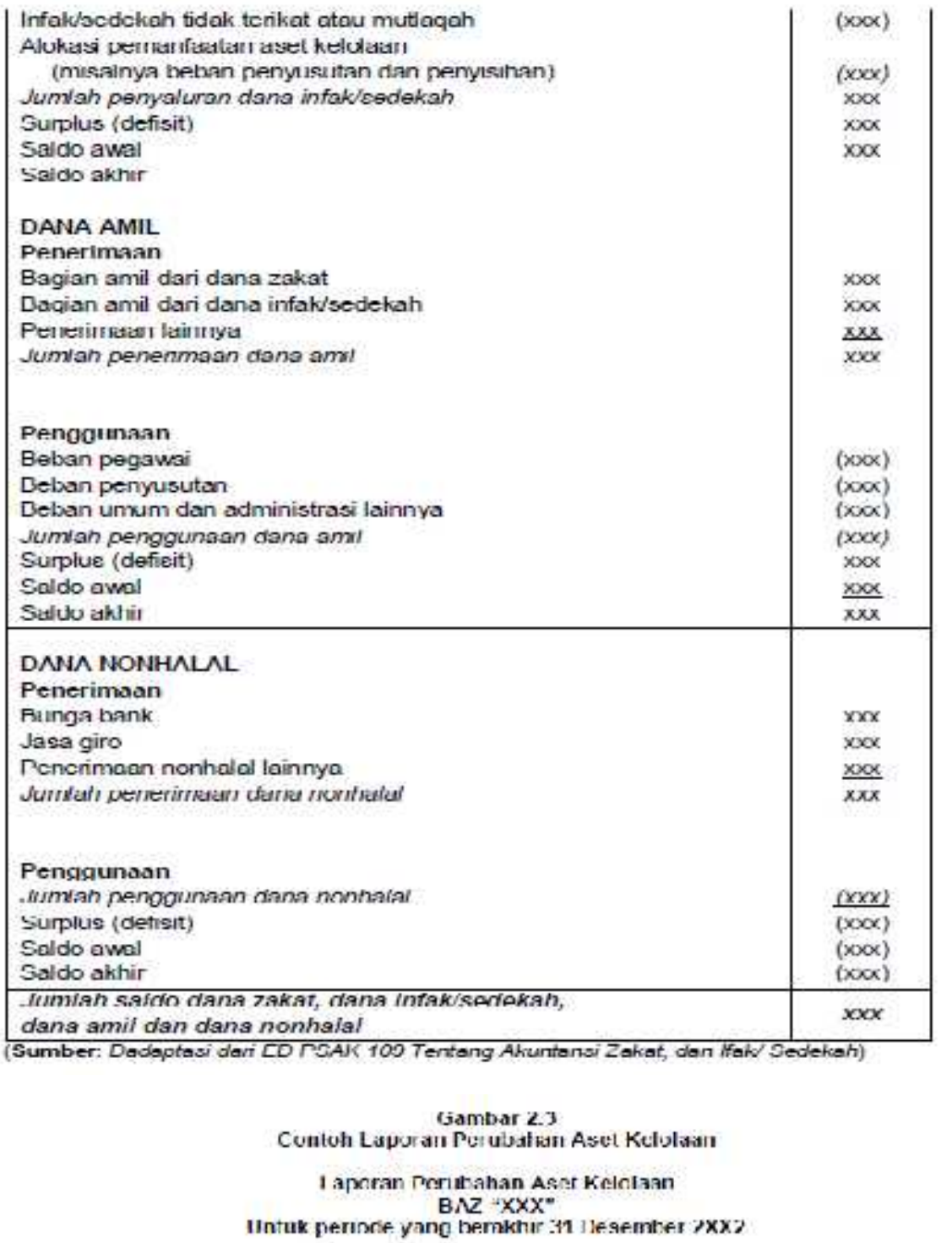

\begin{tabular}{|c|c|c|c|c|c|c|}
\hline & $\begin{array}{l}\text { Saluo } \\
\text { Awal }\end{array}$ & Penambahan & Pyrugutanganati & Pyrnisilian & $\begin{array}{l}\text { Nkunuulasi } \\
\text { penyusunan }\end{array}$ & $\begin{array}{l}\text { Salulo } \\
\text { akhir }\end{array}$ \\
\hline 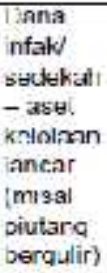 & $x \times x$ & 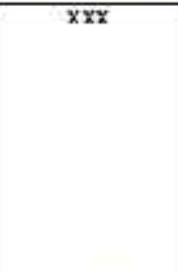 & . & $(\mathrm{x} \times \mathrm{x})$ & . & . \\
\hline 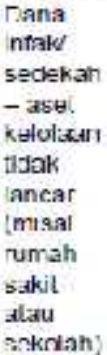 & $x \times x$ & $x x y$ & $\{\mathbf{x} x \mathbf{x})$ & - & $(\mathrm{KXX})$ & $x \times x$ \\
\hline
\end{tabular}




\section{METODE}

Penelitian ini adalah penelitian yang menggunakan studi kepustakaan/literature review di mana penekanan dilakukan pada penggunaan data sekunder. Literature review adalah uraian tentang teori, temuan, dan bahan penelitian lainnya yang diperoleh dari bahan acuan untuk dijadikan landasan kegiatan penelitian untuk menyusun kerangka pemikiran yang jelas dari perumusan masalah yang ingin diteliti. Sumber-sumber bahan acuan didapat dari artikel, penelitian terdahulu, buku, informasi dari internet, dan lain-lain. Tahapan dalam penelitian ini yaitu: pertama dimulai dari memformulasikan permasalahan yang ada, kedua mencari sumber literature yang membahas topik yang diteliti, ketiga mengevaluasi data yaitu dengan melihat dari literature yang ada tentang apa saja yang menjadi kontribusi tentang topik yang dibahas dalam penelitian, keempat menganalisis dan menginterpretasikan, yaitu dengan cara data yang terkumpul dianalisis kemudian diklasifikasikan dalam kategori tertentu untuk memudahkan dalam melihat hasil penelitian.

\section{HASIL DAN PEMBAHASAN}

Hasil penelitian Sularno (2010) bahwa BAZIS milik pemerintah daerah (BAZDA) Daerah Istimewa Yogyakarta masih mempunyai kendala sumber daya manusia yang mana masih merangkap jabatan sehingga BAZIS ini hanya digunakan sebagai pekerjaan sampingan. Mungkin juga, permasalahan seperti ini tidak hanya di Yogyakarta saja bahkan mungkin di seluruh Indonesia. Hal ini sangat tidak kondusif bagi pengelola ZIS dalam seluruh hal organisasi baik itu manajerial maupun laporan keuangan.

Menurut penelitian dari Kristin dan Khoirul (2011) menghasilkan bahwa akuntansi terhadap dana zakat yang dilakukan LAZ DPU DT Cabang Semarang dilakukan berdasarkan nilai dasar tunai (cash basic) dimana model pencatatan transaksi akuntansi yang membukukan semua pendapatan yang sudah diterima. Dalam proses pelaporannya LAZ DPU DT Cabang Semarang hanya membuat laporan sumber dan penggunaan dana dan laporan penerimaan dan penggunaan dana, karena LAZ DPU DT Cabang Semarang belum mempunyai asset sendiri seperti tanah dan bangunan, sehingga LAZ DPU DT Cabang Semarang belummelakukan 5 (lima) laporan keuangan menurut PSAK 109 diantaranya adalah neraca, laporan sumber dan penggunaan dana, laporan perubahan dana asset kelolaan, laporan arus kas, dan catatan atas laporan keuangan.

Senada dengan hasil penelitian diatas, hasil penelitian Fathonah (2013) dan menunjukkan bahwa penerapan akuntansi zakat pada LAZISMU dan BAZDA Klaten samasama menggunakan metode cash basic atau basis kas, yaitu pencatatan dari seluruh transaksi 
hanya dilakukan pada saat mengeluarkan kas dan menerima kas. Sedangkan laporan keuangan yang sebaiknya diterapkan oleh para organisasi pengelola zakat mengacu pada PSAK 109 tentang akuntansi zakat, infaq, dan shadaqah. Laporan keuangan yang dibuat oleh keduanya hanya mencatatkan laporan penerimaan dana zakat dan laporan penyaluran zakat.

Hasil penelitian lain dari Metari (2013), menunjukan bahwa secara keseluruhan dari penerapan akuntansi yang dilakukan oleh Dompet Dhuafa Cabang Makassar telah sesuai dengan PSAK 109 dari pengakuan, pengukuran, penyajian, dan pengungkapan. Namun ada sedikit perbedaan dalam bentuk penyajian saldo dana pada neraca yang dibuat oleh Dompet Dhuafa Cabang Makasar, dimana saldo dana yang disajikan tidak dipisahkan, akan tetapi terakumulasi dari jumlah keselurahan dana ziswaf yang terhimpun.

Hasil dari beberapa penelitian terdahulu dapat diambil kesimpulan dari permasalahan yang muncul bahwa sebagian BAZIS masih banyak yang menggunakan pelaporan keuangan secara sederhana, sehingga cara pelaporan setiap BAZIS berbeda-beda. Hal tersebut dikarenakan salah satunya adalah BAZIS melalui manajer keuangannya belum mengetahui aturan standar mengenai cara penyusunan pelaporan keuangan yang dipublikasi. Padahal pada pasal 19 UU No. 23 Tahun 2011, menyebutkan bahwa lembaga amil zakat (LAZ) wajib melaporkan pelaksanaan pengumpulan, pendistribusian, dan pendayagunaan zakat yang telah diaudit kepada Badan Amil Zakat Nasional (BAZNAS) secara berkala. Hal ini memperlihatkan bahwa sumber daya manusia yang dimiliki BAZIS memiliki kelemahan tentang pengetahuan hukum pengelolaan zakat, infaq dan ahadaqah dan manajemen pengelolaan zakat, infaq dan shadaqah.

Solusi guna menyelesaikan permasalahan yang muncul ditas, diantaranya: Pertama masih banyaknya pengelolaan BAZIS hanya sekedar pekerjaan sampingan saja, untuk itu BAZIS senantiasa berusaha memperbaiki struktur pengurus dan manajemen pengelolaan BAZIS, bahkan bukan tidak mungkin perlunya perekrutan pengurus/karyawan baru dari luar agar mampu memperbaiki sistem dan terciptanya inovasi. Kedua pemaksimalan Forum Organisasi Zakat (FOZ) yang ada di daerah-daerah untuk bersinergi sehingga saling bertukar ilmu dan informasi mengenai banyak hal, baik tentang regulasi pemerintah sampai dengan pelaporan terhadap muzaki. Ketiga perlunya dirutinitaskan kegiatan pelatihan akuntansi ZIS yang berbasis PSAK 109 yang ditujukan untuk manajer keuangan atau staf keuangan BAZIS sehingga pelaporan keuangan dapat terstruktur dan rapi sehingga berefek pada meningkatnya accountability, transparancy, responsibiliti, fairness, dan indenpendensi. Keempat bagi BAZIS yang telah memiliki dana amil yang cukup, disarankan memiliki software khusus 
untuk laporan keuangan sehingga memudahkan Accounting dalam pembuatan laporan keuangan.

\section{SIMPULAN}

BAZIS pada generasi saat ini sudah semakin maju dan kompleks. Perlunya perhatian yang mendalam, baik dari sisi kegiatan maupun dari perlakukan pelaporan akuntansinya. Tujuan didirikannya BAZIS diantaranya adalah untuk mempermudah masyarakat membayarkan kewajibannya berupa dana zakat, infaq, dan shadaqah. Untuk itu BAZIS dalam pengelolaanya harus mengedepankan prinsip amanah dan transparan terhadap masyarakat. Pelaporan keuangan BAZIS diharapkan dan terus diupayakan menggunakan standar pelaporan berbasis PSAK 109, walaupun pada praktiknya masih banyak permasalahan yang menghambat terlaksananya penyusunan pelaporan berbasis PSAK 109.

Kebanyakan dari hasil penelitian dari berberapa BAZIS yang ada di indonesia, memperlihatkan kalau dalam penyusunan laporan keuangan masih menggunakan metode nilai dasar tunai (cash basis) yang hanya melaporkan pemasukan dan pengeluaran dana ZIS saja, sehingga tidak sesuai dengan standar pelaporan yang berbasis PSAK 109. Selain itu, manajemen BAZIS yang belum maksimal bekerja juga menjadi salah satu faktor penghambat, untuk itu perlu adanya beberapa pembenahan yaitu dengan cara perlunya pembenahan struktur pengurus dan manjemen pengelola BAZIS, seringnya diadakan pelatihan dan diskusi bersama sehingga BAZIS menjadi lembaga yang Accountability, transparancy, responsibiliti, fairness, danindenpendensi serta amanah, yang pastinya sesuai dengan syariah islam. Semoga artikel ini bisa memberikan kontribusi positif terhadap semua pihak yang terkait dan dapat menambah wawasan ilmu buat pembaca pada umumnya.

\section{DAFTAR RUJUKn}

Arifin, G. (2011). Dalil-Dalil dan Keutamaan Zakat, Infaq, Sedekah. Jakarta: Elex Media Komputindo.

Departemen Agama. (1989). Al Qur`an dan terjemahannya. Semarang: CV. Al Waad.

Fathonah. (2013). Analisis Penerapan Akuntansi Zakat Pada Organisasi Pen Gelola Zakat (Studi Kasus Lazismu Kabupaten Klaten Dan Bazda Kabupaten Klaten). Yogyakarta: Universitas Islam Negeri Sunan Kalijaga.

Forum Zakat. (2005). Pedoman Akuntansi Organisasi Pengelola Zakat. Jakarta: Forum Zakat.

Gambling, T. E. \& Rifaat, K. (1986). Jounal of Business Finance and Accounthing, 13 (1)

Hafidhuddin, D. (2002). Zakat Dalam Perekonomian Modern. Jakarta: Gema Insani. http://eskultabloidpendidikan.blogspot.co.id/2010/03/zakat-profesi-zakatpendapatan-dan-jasa.html 
Ikatan Akuntan Indonesia. (2008). Exposure Draft Pernyataan Standar Akuntansi Keuangan No. 109 tentang akuntansi Zakat, Infaq/shadaqah. Jakarta: IAI.

Istutik. (2013). Analisis implementasi akuntansi zakat dan infaq/shadaqah (psak: 109) pada lembaga amil zakat di Kota Malang. Jurnal Akuntansi Aktual, 2 (1), pp. 19-24.

Kartika, E. S. (2007). Pengantar Hukum Zakat Dan Wakaf. Jakarta: Grasindo.

Kristin, A. \& Khoirul, U. Penerapan akuntansi zakat pada lembaga amil zakat (Studi Pada Laz DPU DT Cabang Semarang). Jurnal IAIN Wali Songo, 7 (2).

Mahmudi. (2009). Sistem Akuntansi Organisasi Pengelola Zakat. Yogyakarta: PPPEI Press.

Metari, A. (2013). Analisis penerapan akuntansi zakat, infaq dan sedekah pada laz (lembaga amil zakat) dompet dhuafa cabang Makassar. Makasar: Universitas Hasanuddin.

Mu'is, F. (2011). Zakat A-Z Panduan Mudah, Lengkap, dan Praktis tentang Zakat. Solo: Tinta Medina.

Muhammad. (2005). Pengantar Akuntansi Syari'ah. Jakarta: Salemba Empat.

Nurhayati, S. W. (2009). Akuntansi Syariah di Indonesia (Edisi II). Jakarta: Salemba Empat.

Sarif, S.S., \& Kamri, N. A. (2009). A theoretical discussionof zakat for income generation and its fiqh issues. Jurnal Syariah, 17 (3) pp.457-500.

Sularno, M. (2010). Pengelolaan zakat oleh badan amil zakat daerah kabupaten/kota seDaerah Istimewa Yogyakarta (Studi terhadap implementasi undang-undang no. 38 tahun 1999 tentang pengelolaan zakat). Jurnal Ekonomi Isalam. 4 (1).

Widodo, H. \& Kustiawan, T. (2001). Akuntansi dan Manajemen Keuangan Untuk Organisasi Pengelola Zakat. Jakarta: Institut Manajemen Zakat.

Yadiati, W. Teori Akuntansi Suatu Pengantar. Jakarta: Perdana Media Group.

Zaid, O. A. (2004). Akuntnasi syariah: Kerangka dasar, sejarah keuangan dalam masyarakat islam. Jakarta: LPFE. 